\title{
The Politics of Protest Processes: A Portrayal
}

\author{
Laurence Whitehead \\ Department of Politics and International Relations, Nuffield College, \\ University of Oxford, Oxford, UK \\ laurence.whitehead@nuffield.ox.ac.uk
}

\begin{abstract}
This integrated overview of a dynamic field of study covers two main areas. The first half concerns the main internal dimensions of protest movements- their scope and variability, their ideational foundations, and their dynamics, including leadership and resource base. The second half places these movements in the context of their interactions with public authorities, and introduces certain key literatures, including "contentious" politics and the "exit, voice and loyalty" framework.
\end{abstract}

\section{Keywords}

protest movements - contentious politics - resource mobilization - exit - voice and loyalty

\section{Panorama}

In Latin "protestor" meant to assert, testify, testify officially, or bear witness. This usage lingers on today, as those in court charged with offenses "protest their innocence." But by acknowledging a subject's status as an official witness the authorities also grant them standing to make public claims. Contemporary protestors are those who assert their right not only to make claims, but additionally to object when their voices are disregarded. Protestors can therefore legitimately resist public authority within legally determined limits; however, experience teaches that recognized protesters sometimes find themselves officially denied authorized status, notably through reclassification as subversives, or even as "terrorists." 
Although such uncertainties of status may arise from initial distrust/ duplicitous conduct on either side, their more fundamental source is to be found in an underlying instability of the officialdom/protester relationship. From the perspective of the authorities, the benefit of an authorized protest is foreknowledge of its character and choreography. But this comes with a risk of volatility and escalation. From the standpoint of the protesters, authorization provides a secure space for the expression of grievance and resistance. But the associated risk is of succumbing to tokenism and deflection. Neither side is necessarily a unitary actor. Under the pressures of confrontation, both can become unstable coalitions whose judgments and strategic calculations may shift over a cycle of protest dynamics.

Not all protests are political or indeed collective; for example, in the modern family a child can protest against a parent. A conscientious objector may protest against a war through personal refusal without any wider involvement. Similarly boycotts can express a private rather than a collective sense of repudiation. But this article deals only with claims and objections expressed in the "public" sphere, and therefore at least implicitly directed toward officialdom. Nowadays the relevant authorities are mainly states, although the Protestant religion was directed against the Roman Catholic church, and both international and sub-national organizations can equally be the targets. Where the authority of two states clashes, they may exchange official "protests," again reflecting the original meaning of the verb.

Beyond such explicitly "political" authorities as states and governments, public protests can also be directed against many other targets, ranging from military bases, business corporations, courts, political parties, and media enterprises to schools and universities. Such episodes also fall within the scope of public contestation. The realm of the "political" in these protests extends to a very wide range of collective activities that, while not strictly official, may resort to the constituted authorities for assistance if needed. So, all political protest implicates public power, at least indirectly.

In a world composed of territorial states, nearly all constituted authorities allow for some category of "legitimate" peaceful protest and provide protocols for its permitted conduct, even though the conditions imposed can be intensely restrictive in some settings. But such orchestration is an elaborate social construct, not a self-evident given. It involves learned patterns of behavior that need to be assimilated by both sides and internalized by public opinion. As such, its limits have to be negotiated and updated over time, within boundaries that are likely to prove shifting and permeable. Pre-modern reflexes of intolerance and closure lurk in the background, and even under favorable conditions key questions remain open. Which sectors of the population should be 
authorized to protest, and under what restraints? Which other potential claimants (ethnic minorities, suffragettes, refugees, other heterodox dissenters) can be denied such recognition and voice?

Protest can also be expected under conditions of anarchy or power vacuum. In such conditions the claimants usually demand the establishment of public authority where it is lacking. Although the core issues of political protest concern the dyadic relationship between public authorities and collective claimants, a third element should always be considered - the bystanders (or public at large) whose potential alignment with one side or the other can tilt the balance between them. Protest movements are thus triangular affairs (Rucht 2007).

This introductory article provides an overall portrayal of the whole complex and diverse panorama of "protest politics." It is a tentative integrated overview, not a complete portrait or a full inventory of this rapidly developing field of study. It aims to provide a current tour d' horizon to encourage the more detailed and conclusive enquiries soon to be hosted in these pages. Some aspects of this subject are already quite developed, mostly undertaken by western political scientists and mainly concerned with nonviolent protest movements operating under fairly stable and legitimate constitutional conditions (e.g. Gamson 1990; Kriesi et al. 1995; Rootes 2003; Tarrow 2021). But more recent scholarship has also extended the scope of the enquiry (notably in Latin America and across the Global South), and the geographical and historical coverage of this Journal will encompass a range of other conditions (Dalton and Van Sickle 2005). Multi-disciplinary methods will be required, including discourse analysis, protest event analysis, ethnography, history, psychology and of course sociology (e.g. Touraine's method of sociological intervention, 1978).

Periodic manifestations of collective protest are an inherent feature of political activity in almost all contemporary societies, as well as the vast majority of earlier systems of authority. The theoretical exceptions are very rare, if indeed they exist at all. The traditional view of protest as an "abnormal" phenomenon has long been discredited.

Hypothetically there are three limit cases where it could be supposed that all political protest might be eliminated: $i)$ theocracies where secular power is derived directly from divine instruction, so that to question it is sacrilege; ii) so-called "totalitarian" regimes which recognize no private sphere of activity or any limits on the power of incumbents to terrorize all possible dissidents; and perhaps even iii) an extreme "end of history" scenario in which ideological disagreements are all superseded, and "politics" of every variety has given way to technical administration, with allocative decisions consensually resolved by market or electoral mechanisms only. Whether any of these three possibilities 
could ever be fully realized in practice may be doubted, however. Even the most overwhelming variants of divine rule involve some degree of interpretation that raises matters of doubt for some believers; the suppression of private opinion under totalitarian conditions always generates "internal exile" and covert forms of resistance that provide the germ for an eventual re-emergence of protest as soon as the intensity of repression slackens; and however relentlessly administrative and market logics may seem to encroach upon the "political" realm, history and contention only retreat in order to resurface under a different guise. In other words, protest may be redirected but never eliminated.

Thus, for practical purposes political disagreement is a universal reality and provides a foundation for certain expressions of protest against prevailing authority in all settings. Although open expressions of dissent can intermittently be made impossible in some regimes, even under these circumstances individualized or passive forms of protest still provide fertile soil for the eventual re-emergence of more coordinated and assertive forms of public claim-making. In such conditions the repressive backdrop tends to generate more inexperienced and potentially explosive forms of protest (Tilly 2010). Although some protest movements may appear to be directed against non-governmental targets, such as immigrants, airports, or mining companies, they remain "political" in the sense that they agitate either to change some aspect of public policy or to remonstrate with their rulers for failing to act on some matter of community concern. Wherever some kind of public sphere exists, acts of authority will periodically be challenged and some form of political protest will arise.

This portrayal proceeds in two stages. The first part involves sketching the diversity, ideational basis, and dynamics of the protest movements themselves. The second part of the article turns to the contexts in which protest movements operate and how they interact with the authorities they seek to influence.

\section{Varieties}

This sweeping panorama necessarily encompasses a wide array of protest phenomena. These range from deferential petitions, sit-ins, and passive civil obedience to massive peaceful marches and rallies, global internet campaigns, and street blockades backed by the threat of intimidation. Outright rebellion may fall outside the scope of this topic, but the line separating extreme protest from frontal subversion is fuzzy and subject to discursive manipulation.

On another axis, the duration of a protest movement can vary from a single flash event to weeks or months. The Algerian hirak (movement) that started in 
February 2019 continued every week for over a year, and in practice the movement persists over two years later. The Madres de la Plaza de Mayo in Buenos Aires have protested at regular intervals for over thirty years. On an even longer timescale, the American civil rights movement began over a century ago with protests against lynchings that carry right through to the present day (Francis 2014).

Some protests arise over very specific issues that are only of limited collective concern (the closure of a local hospital, for example), whereas others can be of lasting and nationwide significance (e.g. Freeden on Greenham Common, 2013), and still others are global in coverage (Extinction Rebellion). Small, modest, initial protests can catch the collective imagination and leapfrog into much more ambitious campaigns. This has become known as "upscaling" (McAdam et al. 2001), while rapid deflation of over-extended claims can also downscale into more limited hardcore protests.

Other criteria of classification include the axes of reformism/revolution, violence/nonviolence, and realism/utopianism. Some movements are rigorously autonomous and resist association with political parties or other programmatic agendas, whereas others are essentially fronts for more structured organizations (including factions in power using protesters against rivals). Movements can also be classified by their ideas, their resource bases, and their leadership structures, as we shall discuss further below. But since spontaneity is often the hallmark of effective protest, improvisation and boundary crossing tend to destabilize over-rigid classifications (Snow et al. 2014). Following Tilly, Della Porta (2020) refers to repertoires of protest "defined as a non-conventional form of action that interrupts daily routine in order to attract the attention of the public and influence elites" $(657-58)$. However, in some societies such protests may become so regular as to undermine the description "unconventional" (strike action, for example). Moreover, "attracting attention" is only one possible objective. The political protests of greatest import aim to pressurize policymakers into changing their conduct. Repertoires of protest range from petitioning authorities to intimidating them. They can seek to persuade, but also to compel.

\section{Ideas}

Every protest movement needs to develop a supportive narrative resting on some more or less coherent ideational foundation. When protesters present their claims, criticisms, and arguments for resistance and formulate their alternative projects, their ideas may well seem incoherent and unstable. Although 
one source of argumentation is sure to arise from a view about the failings of the existing order, other derivations may be just as important, such as ideas received from the wider world, dissident ideological traditions (Mahatma Gandhi's satyagraha concept of holding on to truth by nonviolent resistance to evil), or perhaps even outright utopian inventions. Moreover, such constructions are often labile and polysemic - that is to say, they are liable to evolve and adapt in unanticipated directions, with discordant tendencies competing to direct them in one direction (e.g. more reformist or more radical; Benford and Stone 2000). A further factor complicating the production of protest narratives is that they also face the test of how to connect with constituencies whose engagement is needed to energize the movement. The protest will only prove durable and effective if its ideas reach out to the grievances and aspirations of an initially inattentive wider public.

Such features complicate the task of assigning protest discourses into neatly prefabricated categories. Still, a distinction can be made in broad terms between reactionary, traditionalist, reformist, radical, and nihilist framings of the protest agenda. Some examples may bring these labels into focus. The protest movement that brought down the Shah and his westernizing "White Revolution" in Iran in 1979 was mainly orchestrated around the reactionary agenda that had long been developed by the Ayatollah Khomeini. The 2008-2014 "yellow shirt" protests against the "red shirt" governments aligned with Populist leader Thaksin Shinawatra eventually prevailed and reinstated traditional authority there. The "Arab Spring" protests in Tunisia in 2011 that brought about a constitutional democracy can be seen as serving a reformist ideational agenda. The 2019 estallido of mass protests against Chile's neoliberal ascendancy qualifies as a movement based on a radical critique of the prevailing order. Finally, the 2001-2002 protest agenda in Argentina coalesced around the nihilist slogan "Que se vayan todos!" (get them all out). Here we have a set of five extremely vigorous and impactful nationwide protest movements, which despite some processual commonalities were galvanized by strikingly contrasted ideational agendas. Similar distinctions can be made concerning smaller scale and/or less successful protest movements that likewise embraced highly divergent ideologies and doctrines.

In practice a mélange is common, and rank and file protesters are often attracted to more intuitive and even emotional appeals than might appear from the language of the associated intellectuals and policy entrepreneurs. Group loyalties may over-ride the finer points of leadership doctrine. Tensions between the alternative ideational framings are often managed by escalating the intensity of protest emotions. The symbolic appeal of a heroic or 
salvationist leader may serve to paper over the ambiguities of the movement's programmatic offerings.

\section{Dynamics}

Whatever the ideational content of a mass protest event, there are also dynamic processes involved (McAdam et al. 2001; Bishara 2015; Onuch and Sasse 2016). These can be separately considered. Timing, sequencing, and location are critical. What trigger conditions are first required to bring enough protesters together? What sites of collective expression are critical to its development? What cycles of development (and eventual demobilization) are to be expected? What leadership structures are involved, and how does this change as the authorities shift from one management strategy to another? All protest movements can be inspected from the standpoint of these four dynamic considerations.

Before any visible protest activity appears, there may be widespread discontent and a latent desire to challenge the conduct of prevailing authorities. But such conditions can persist indefinitely without precipitating open resistance, and protests can also erupt even in settings where collective opinion is not initially that disaffected. Every movement will claim to be expressing a widespread demand for change, and that may be true, not infrequently such demands for change really crystallize only after the movement has staked its claim, and largely as a result rather than a cause of protest activism. So, it is necessary to investigate trigger conditions for protest without making prior assumptions about their starting base of social support. An extended buildup of tension is one possible cause. Others include an external shock, a cathartic event, a succession crisis, an identitarian outburst, or a misjudged repression.

Some major protests are the product of years of advance planning, careful preparation, and strategic calculation. They are triggered by a directive from a leadership group. Iran in 1979 and Thailand in 2008 seem to fit this pattern. But protest outbursts may also erupt almost spontaneously. Here the authorities are caught completely unawares, with no identifiable challenger to monitor or co-opt. That happened in Argentina in 2001-2002, in Tunisia ten years later, and with the Black Lives Matter upsurge of 2020. Such eruptions can disorient the police and may panic a normally vigilant ruling group. Collective caution (or fear) abruptly dissipates, empowering protesters and perhaps causing the authorities to lose control. Protest then feeds on its own success. Even the most unexpected of outbursts emerge from precursor activities. What first 
seemed like futile gestures can be recast as prophetic stirrings once there is a breakthrough to be explained (Kriesi, Hutter, and Bojar 2019). While farsighted inspiration is certainly possible, such antecedents should not be taken at face value without careful probing.

Whether spontaneous or pre-planned, the launch of a mass protest campaign requires both a start date and at least one key site where a large population can assemble at a precisely defined time. This is a key resource, but also a crucial point of vulnerability. Consider Tahrir Square in Cairo. The Mubarak regime had become accustomed to monitoring and thwarting such episodes before they got out of control. But the activists had learnt from past experiences of police repression. Inspired by Tunis, they managed to gather in a digitally coordinated sequence of small groups near Tahrir square, in order to converge on it at an agreed time before the authorities could crack down. Once in place - and covered by international media (Hussain and Howard, 2013) they sustained a compact "liberated zone" of free expression. This dispelled the usual climate of fear and apathy, attracting a cascade of reinforcements that deterred effective suppression and culminated in Mubarak's ouster. However, control over such a visible and strategic site could also be wrested away from the protesters, leaving them exposed to dispersal and retaliation. Ketchley (2019) reconstructs how the initially promising Tahrir strategy of fraternizing with the military eventually backfired.

Tiananmen Square provides a further variation. There the authorities hesitated but did not yield. The youthful idealism concentrated for a few weeks in a single symbolically strategic location led the protesters to misread their strength in the society as a whole (Castells 2012). Beyond Tahrir and Tiananmen, other relevant locations include Tlatlelolco (Mexico City, 1968), the Casa Rosada (Buenos Aires, 2001), central Kiev (2014), and Hong Kong (2019).

Key sites need not necessarily be located in capital cities (compare Cordoba, Argentina, 1968 or Barcelona in 2017). Protests can also gather momentum in peripheral locations before concentrating in central sites (the gilets jaunes began in rural France). Algeria's hirak originated in the isolated small community of Kherratta in Kabylia, a week before it spread nationwide and swamped downtown Algiers. Some such peripheral protests can be isolated and bottled up before they reach a wider audience, such as the Moroccan Rif Mountains in 2017-2018. Whether locally contained or spreading like wildfire, the geographical arena chosen for protest action is a critical aspect of each movement's dynamics. Roadblocks, campus occupations, and demonstrations outside military bases all acquire their impact from the choice of sites where they occur.

As the term "movement" suggests, an eruption of protest is not a stable development. It has a start point, a trajectory, and a moment of culmination 
or reflux. So, the dynamics of protest also invite a cyclical perspective. Recent studies have drawn attention to the snowball effect, by which an initial group of highly motivated risk takers create conditions under which successive waves of participants can be drawn in and claims can be radicalized (Klandemans 2014; Jasper 2014). Later arrivals have demographic and attitudinal profiles that differ from those of the originators, and they may therefore redirect the movement into unintended paths. New aims can be added to the list of demands, different tactics may get tried out, and the locus of leadership may shift. For example, in the case of Tahrir Square the initial protesters were secular, and for a while the Muslim Brotherhood held back. Once the Muslim Brotherhood joined in, however, the movement was reconfigured, and perceptions of the challenge it posed varied accordingly (Durac 2015). As support for the protest mounted, bystanders began to reassess their estimates of the chances of success. A further cohort of backers included participants with a more calculating and instrumental outlook than that of the first movers. In due course, unexpected momentum and sweeping success can elicit a matching and perhaps even more forceful counter-movement, with the potential for a crushing backlash (Tarrow 1994, chap. 10).

Tunis and Cairo demonsrated that initially spontaneous, nonviolent mass protests can escalate to produce wholesale regime change. This produced powerful demonstration effects across the Arab world. But from a longer-term perspective, the eventual outcomes triggered by these processes were very mixed and mostly regressive. For this reason, "protest event analysis" (Koopmans and Rucht 2002) needs an extended timescale. Otherwise, it would fail to explain the real consequences of extended protest processes.

One ambitious but over-schematic example is provided by Chenoweth and Stephan (2011). Building on the large data quantitative approach pioneered by Gurr (1970), they assembled a data set on major civil resistance and social movements around the world between 1900 and 2006, attempting to uncover underlying regularities and clues to the requirements for success. According to their highly stylized account, nonviolent mass movements were twice as likely ( $53 \%$ of cases) to "succeed" as violent movements $(26 \%)$. They think this may be because the former can recruit many more participants from a broader demographic, although it could also be that violence is mostly the last resort against the most immovable of regimes. According to their findings, once $3.5 \%$ of the total population have been enlisted into open protest success is assured; although doubts concerning both their metric and their predictions have been reinforced by the Arab Spring and later experiences in the Maghreb and Myanmar. 
Therefore, key issues include who speaks for the movement, how it is led, and what scope it has for a negotiated solution. The ethos and tactics of the originators may well prove at variance with the outlook of many in the mass movement, as well as the strategic incentives created by its success. These are critical determinants of the later stages of its trajectory-whether it ends up splintering, compromising, or clinging on to its initial purity as the passage of time erodes its momentum. All such movements run their course. They generate social capital that provides leverage. But eventually that capital will have to be deployed, either through institutional reform, escalating confrontation, or nostalgic dispersion. These three alternative pathways are illustrated by current political experience. Thus, the cycle of mounting protests in Chile that culminated with the mass "estallido" (outburst) of October 2019 proved sufficient to induce a reluctant government to convene a constituent assembly with the power to replace the extant illegitimate constitution. By contrast, the initially peaceful but eventually uncontrollable mass uprising against Mynanmar's 2021 military coup currently seems destined to a tragically violent escalation. Third, massive pro-EU demonstrations in London have proved predictably vain given the referendum verdict, with momentum dissipating as the "remainers" relapse into nostalgic dispersion. Likewise, the legacy of the Tiananmen protests now seem close to extinction.

The fourth and final heading for consideration under this dynamic perspective is the movement's leadership structure. A nihilist protest can repudiate all attempts to create a stable leadership. In this case, the protesters are united only in what they oppose, and any claim to speak on their behalf can be repudiated as a source of infiltration and betrayal. Radical movements may also resist the creation of any structure of command, on the perhaps well-founded basis that to name leaders is to invite decapitation. One reason why some promising protest movements fail to maximize their potential is that in the absence of organized direction they cannot adjust to the opportunities created by their success. The Tiananmen movement arguably suffered from this problem, as did the Mexican students of 1968. However, this argument should be treated with caution. Neither the Chinese Communist Party nor the Mexican PRI were trustworthy counterparts given their well-honed and notorious talent for co-optation and control (Yan et al. 2020).

Most protest movements develop at least some leadership. An inspiring individual (such as Nelson Mandela or Aung San Suu Kyi) may provide the key source of direction and the sole authority capable of reaching a settlement. If that iconic figure is taken hostage, no one else has the capacity to call off the protesters. Hostage-taking authorities may keep the leader alive as a bargaining chip in reserve, as well as a potential interlocutor to restrain protesters. 
Once the leader is eliminated, the confrontation becomes more zero-sum (the Navalny issue).

Between the poles of no leadership and a highly personalized figure lies a spectrum of intermediate options. Such leaders have to continually strike a balance between protecting their credibility as exemplary protesters and using their authority to navigate their movement toward a settlement. Leading a mass protest is a challenging task. Lines of control are weak and opaque, reliable information is scarce, and when the movement seems on an upsurge rivals have more incentive to challenge for top positions. Factionalism is ever-present in expansive and confrontational protest movements.

Different issues arise for leaders of single-issue protest movements within a broadly reformist context. In place of a surging pattern of cumulatively more ambitious episodes of protest, the focus on a narrow range of demands may become routinized, while supporters of the movement are tapped for funds in a sequence of campaign drives. Here there can be considerable scope for expertise and career enhancement at the top. There may even be a premium for conventional management skills and career paths available, meaning that successful protest entrepreneurs can move on from one leadership role to another. Rank and file supporters are more easily led in these cases.

\section{Resources}

Some protest movements draw on great sources of organization and support. The Ayatollah Khomeini's followers could always count on vast human and material backing channeled through Iran's Shi'a mosques. The yellow shirts of Thailand had back up from the monarchy and its many military, bureaucratic, and business allies. Some reformist protesters are also well-supported, for example, by western NGO s, German-based party internationals, and perhaps even some universities, or - as in Brazil and Poland - trade unions. External support can tackle key organizational questions, such as how to finance the costs of a prolonged campaign, how to communicate reliably with the support base, and what protection can be provided to victims of official reprisals. But when a protest movement gains traction it will incentivize incumbent authorities to intervene and ward off such backers. Even the best-placed protest movements face unstable conditions, while most have to operate on a shoestring and hold together through hardship and sacrifice rather than through conventional support.

The literature on the resource mobilization underpinnings of social movement activism is extensive (Zald et al. 1987) and has improved upon previous 
collective action theory without repudiating its economistic assumptions. But in the case of active protest movements, the resources involved are largely emotional and identitarian. This limits the utility of any rational choice model of collective action. When students and monks expose their bodies to live fire from army snipers on the streets of Myanmar, or Chilean protestors turn out in Santiago so that carabineros can blind them with rubber bullets, the psychological resources of these protesters far outweigh the support and guidance that their leaders can supply. However, even radical movements need some communication and resources, and such matters become central to the evaluation of more limited/reformist protest campaigns.

Although tracing the sources and uses of financial resources always provides a valuable entry point for the study of any organization, in the case of protest movements it is the flow of information rather than of funds that merits the most attention (Cammaerts et al. 2013) As noted in section III, ideas are what most holds protest movements together, rather than interests or financial rewards. The potency of ideas depends upon their effective dissemination, so this organizational task takes precedence over all others. A movement, however lacking in funds and other material resources, can take off with clear and inspiring messages that are well communicated to the right audiences. Protest communications can be assessed by examining the message, the medium, and the audience.

In order to be effective, protest communication messages need to be clear, direct, and engaging. A summons to action should explain why, how, where, and when protest is required. Traditional methods included the distribution to households of leaflets containing such information; the announcement of marches and rallies (often involving negotiation with the relevant authorities to redirect traffic and provide security); and press interviews and broadcast messages. Such methods are now very out of date. Social messaging and online chats provide the main new conduits. Instant on-site recording of contentious imagery conveys a more personalized and emotive message than earlier protest communications. In real time supporters can receive visual demonstrations of how to conduct themselves, together with where and when. The authorities are more likely to be caught unawares rather than consulted in advance. All in all, these changes in the medium of protest communications have strong effect on the associated messaging. Top-down planning and direction of protest events tends to be replaced by horizontal on-site networking, and structured messaging is liable to give way to fragmented viral expressions of personalized experiences. This can make it harder to arrive at any coherent interpretation of what a protest event was really about or how it unfolded (Tufekci 2017). The 
storming of the US Capitol on January 6, 2021 provides the most recent high visibility instance of these issues.

\section{Types}

Thus far this discussion has concerned the internal aspects of protest movements - their content, structure, and dynamics. These practices also need consideration in their external settings. Here Weber provides a convenient entry point (Weber 1947, chap. 3) through his threefold menu of authority patterns. Under A) traditional forms of authority, the most potent patterns of protest are likely to be those that invoke precedent and appeal for the restoration of past entitlements. Channels of protest sanctified by custom will be safer and easier to activate than those that can be condemned as external intrusions. In contrast, B) rational-legal systems of authority can more readily be assailed by reference to considerations of functional efficiency rather than by invocations of an archaic past. The best avenues of protest will therefore be those that can be presented as progressive and well-tailored to the logic of modern public service. "Irrational" forms of protest will be met with more resistance. Weber's third option, C) charismatic authority, will stimulate a more diverse range of protest responses. Some of these responses are based on repudiating the regime's foundational claims to rulership, while others buy into the prevailing discourse with the aim of subsequently softening or redirecting it. Here protest aimed at restoring the status quo ante will meet the strongest resistance, while attempts to promote modern public service may be tolerated on an instrumental basis, and protests directed towards taming the charismatic authority may make headway if and when that authority loses momentum (or is "routinized" in Weber's parlance).

This first approximation to a typology of political protest patterns is highly schematic, of course. Further crucial considerations arise from beyond these regime types. Whether authoritarian or liberal, traditional or modern, charismatic or rational, all these authorities are constituted in an international context that also conditions the available pathways of protest against them (Della Porta and Tarrow 2005). Geopolitical rivalries and international power asymmetries can reshape the contours of protest. Global trade and investment flows impose further constraints and incentives affecting protest opportunities and campaign options. Modern digital communications create a dense new network of transnational information flows and lobbying possibilities that recast the dynamics of protest action (Maddison and Sawer 2013). Populist 
and nationalist backlashes against perceived erosions of domestic sovereignty add further cross-pressures to the mix, as movements empowered by their external positioning elicit counter-protests by those lacking such international connections.

\section{Contention}

For the founders of the "contentious politics" school of analysis, "regularities lie elsewhere than in standard sequences, whether scripted episodes, protest cycles, or otherwise. Regularities lie in mechanisms that bring in new actors, eliminate old ones, transform alliances, and shift the strategies of critical actors. By identifying which mechanisms and processes put an episode of contention in motion and where they take it, we can better understand why some episodes are brief, while others are protracted and lead to the implosion of some regimes and the creation of new ones" (Tilly and Tarrow 2015, 15). They identify a repertoire of processes and mechanisms of which protest is only one-others include brokerage, certification, mobilization, demobilization and scale shift. All these procedures involve challengers making claims "with their targets, public authorities, and third parties like the media and the public in sequences of interaction" (14). Beyond the confines of narrowly conceived "protest" politics, they wish to study "how political actors make claims in the name of their political identities, identify various sorts of collective performances, describe how contentious performances cluster into repertoires of contention...(and)... analyze how repertoires change" (13). Therefore, this framework is wider and more interactive than the portrait provided above, and it also places more emphasis on causal mechanisms as opposed to discursive practices. Of most interest here is to consider how this account of protest cycles relates to their larger repertoire of contentious political practices.

Protest politics are directed against policies or powers employed by governing authorities. The argumentative starting point for such activism is that unless we actively object and obstruct, these ills will continue unabated, and those who benefit from them will escape the sanctions they deserve. Without our protest these ills will persist or intensify. This can involve a more foetused foundational critique of existing authority than most of the behavioral practices nested under the rubric of "contentious politics." That is why the protest agenda foregrounds discursive features whereas the contention focuses more on causal mechanisms. From a radical discursive standpoint, even if we are sure to fail (as nihilist protesters may believe), we can at least give testimony to our repudiation of abusive power. Even if the golden past is irretrievably lost 
(as traditionalists and reactionaries may accept), it is not forgotten and those who have betrayed their heritage should be held to account. Even reformist protesters can value their campaigns for their own sake, more than as just a means to some instrumental end.

Protest is affirmative, not just instrumental. It expresses what Weber called an "ethic of conviction," whereas the mechanisms and repertoires of the contentious school invokes tend to highlight the ethic of responsibility. Admittedly their repertoire of contention provides no guarantee that desired results will be achieved; however, its rationale for action and its criterion for selection of methods is more results oriented. Note, however, that this is a difference of degree, not of kind. The contentious school recognizes the relevance of identitarian considerations, and even the most exalted of protest activists have some interest in achieving results, as well as parading their convictions. In fact, much of the dynamics of a protest cycle arise from the shift over time from an ethic of principled opposition toward a calculus of achievable results.

Like protest politics, the contentious politics framework is intended to be a general approach to comparative analysis. However, the contentious model originated from experiences in the USA in the 196os and 1970s and may work best in situations where, even though deep differences of outlook persist, the solidity of the institutional system offers good grounds for believing that good results are attainable if the right pressures are brought to bear. While the study of reformist protest sequences can benefit from the regularities uncovered by the contentious school, their toolbox needs some stretching to fit other patterns. Examples include the opacity and instability that so often characterize protest politics in weakly institutionalized settings (Kingstone et al. 2013) and the existential dilemmas that can arise when desperate protesters take on implacably repressive rulers (Whitehead 2020). Some tools in the repertoire of contention (such as brokerage and certification) presume an orderly context that may be unrealistic in what has been characterized as a "protest state" (Moseley 2018, 97-98). Moseley doubts the applicability of contentious "brokerage" under Argentine conditions of manipulative "clientelism". Argentina provides an exemplary case of unstable institutions and a chronically repetitive sequence of frustrated protests. Contentious protest is even more distorted in the harshly intolerant setting of Maduro's Venezuela.

The contentious school do acknowledge that where government authority is weak, the risks of engaging in contentious mobilization is enhanced, and they have developed concepts and tools that are available to political activists of a conservative or reactionary disposition as much as to those who are "progressive." They know that emancipatory social movements can elicit equally or even more powerful counter-movements. They recognize that heightened 
unpredictability and the admixture of violent components makes for acutely non-linear sequences. With so much at stake and such great uncertainty about the available trajectories, contentious actors may switch positions abruptly, form improbable and unstable coalitions, and invite in extra participants (so called "white" and "black" knights) who often prove disruptive and disloyal players.

Albert $\mathrm{O}$ Hirschman fled from Weimar Germany as Hitler came to power in 1933, so he knew from immediate experience that under some circumstances previously productive avenues of political expression can be violently suppressed. His "exit, voice, and loyalty" framework provides an alternative, generally applicable model worth comparing with that of the contentious politics school (Hirschman 1970). All protest can be driven underground, and non-activists can be forced to choose sides. Even so, resistance to abusive authority remains a latent potential. Indeed, the lesson of Weimar and many other experiences is that it is far easier to suppress open protest and exile dissidents than it is to permanently silence their ideas. Many protest movements remain operative from exile, with their messages transmuted and perhaps radicalized rather than silenced. Any general portrayal of protest politics must therefore consider the full range of historical variants.

\section{Hirschman}

Hirschman's contribution adds several important features to the study of protest politics. First, it offers some micro-foundations for collective action. Second, it connects such political behavior to wider social science theorizing, and in particular economic (cost benefit) modeling. Third, and most importantly, it provides an interactive (one might even say a dialectical) account of how protest movements not only bring pressure to bear on their targets but are also modified by the reactions they elicit.

For Hirschman, when political scientists tackle issues of dissatisfaction with the collective provision of goods and services (public and private), they overstress the importance of rebellion, whereas economists focus too much on withdrawal, such as when a consumer switches to a better-value provider. Instead, an integrated political economy framework could usefully combine the insights of both approaches. This proposal is relevant to protest movements, since they combine features of both behaviors. Protest repertoires include acts of open rejection of established authority ranging from boycott and electoral abstention to non-violent civil disobedience. 
Attention to the micro-foundations of individual action adds a dimension that is easy to overlook when studying collective behavior. Protest movements not only face a choice between alternative tactics for influencing public authorities; their supporters also have options as they assess whether the movement is performing as they require. They too can double down on their active engagement with a successful protest (enthusiastic "loyalty"). In cases of doubt they may also choose to hang back and hope for the best (reluctant "loyalty"), or they can "voice" their preference for a change course; if that fails, they can "exit," either by quietly fading away or by actively withdrawing their support. Like consumers and voters, protesters make judgments of their own and monitor and evaluate group behavior from their individual perspectives. They also have other commitments that compete for their time, attention, and resources.

This framework is behavioralist and rationalist. That provides the model with generality, simplicity, and clarity. From our standpoint, however, it detracts from the contentious and discursive features of protest politics. These too can be studied empirically and should thus not be omitted as "unobservables." The three behavioral options rest in particular on attitudinal alternatives that can also be modeled. Additionally, there are three broad attitudinal stances that at first sight may seem to correspond to the behavioral alternatives-resistance, engagement, and acceptance. But on closer inspection these attitudes are not in perfect alignment with Hirschman's triadic repertoire of behaviors. Thus, an attitude of resistance to authority could lead to various types of "exit" behavior, including civil disobedience. But it could also promote opposition expressed through the activation of all available channels of "voice." Likewise, an attitudinal disposition favoring participation and engagement could be expressed through the behavior of "voice" but also matches positive versions of "loyalty." Finally, acceptance is an attitude that can be tacit and reluctant, as well as trusting and supportive.

Thus, the Hirschman behavioral triad is powerful but over-simplified. Its great merit is to draw attention to the shifting calculus of costs and benefits that constrain the conduct of protest actors and participants. But a usable portrait of protest movements needs to draw on the influence of attitudinal and discursive sources over these calculations and their bald behavioral outcomes. More than three alternative trajectories merit consideration, and their boundaries are unstable. Individual protesters navigate between a limited repertoire of tactics (active dissent, background support, passive resistance, internal exile, recantation) as their personal circumstances dictate.

Collective movements of protest can be hard to pigeonhole into neat classificatory schemas. They may adopt multiple overlapping strategies. For 
example, recent migrant caravans from Central America can be seen as simultaneously involving i) organized exit from a corrupt and unreformed political regime; ii) the articulate voicing of a coherent domestic agenda in repudiation of the incumbent authorities; iii) an appeal to the loyalty and solidarity of a transnational community wedded to the defense of fundamental human rights; and iv) the collective support for emigrants, for whom a caravan may provide a safer route to the US border than the alternatives available from corrupt intermediaries (coyotes).

\section{Dialectics}

The "exit, voice, and loyalty" framework also provides an interactive (indeed "dialectical") perspective on the two-way relationship between protest movements and the authorities they target. In fact, this may be Hirschman's most important contribution to our topic, and it marks a significant contrast with "movement-focused" approaches that focus on what one side is seeking rather than how the two sides mutually adjust. This shift in emphasis generates a larger set of protest repertoires, dynamics, and trajectories. In a later contribution (Hirschman 1974), he acknowledged that his initial model was geared toward the status quo, presuming that under optimum conditions a firm (or state) will receive signals of customer (or citizen) dissatisfaction and adjust accordingly to restore the relationship. From a functionalist standpoint, one might model political protest as an early warning system that performs a steering function to keep government on an even keel. Reformist protesters may explicitly justify their conduct on these grounds. But the most consequential protest movements seek, and sometimes achieve, more drastic changes of course than required merely to keep the ship of state afloat.

Indeed, an embedded culture of political protest can develop that produces gridlock and blocks collectively beneficial reform. Intense protests can also reflect foundational disagreements over the nature and purposes of political order. The trajectories of movements can be modeled in interactive terms, regardless of whether such movements are seen as functional, dysfunctional, or re-foundational. As discussed in IV) above, movements unfold according to a dynamic temporal logic, and their course of development and eventual results depend on how the authorities respond to their pressures as well as to their internal volitions. An effective protest movement must adjust to the expectations and responses of its adversaries and targeted opponents while simultaneously maintaining the allegiance of its supporters. 
Incumbent authorities also have a repertoire of options at their disposal to respond to protest challenges (Rich 2019). They may initially choose lofty indifference on the basis that challenges will fail to gain traction or fade of their own accord. They could also consider pre-emptive repositioning, or adopting some cosmetic features of the protest agenda in order to defuse the core. When the costs of unresponsiveness increase, authorities have the option of bargaining with moderate protesters to outflank the radicals. This requires increased official attention to the challengers and their sources of support. When incumbents come under pressure to explore areas for compromise, their intelligence agencies are likely to be scoping out the threat potential of the more intransigent protesters. As the state increases its responsiveness, it will also invest more energy in securing its ascendancy and, if necessary, preparing for a punitive reaction. By the same token, as the protesters find themselves being taken more seriously by the authorities, they will need to step up their understanding of the opportunities and risks of compromise. Their tactics, strategy, and leadership coherence will be tested, and they too will need to brace for possible retaliation if no agreement can be found. Such interactive and cyclical features of protest dynamics will shape their trajectories and determine which type of movement eventually takes shape.

Classifying, comparing, and monitoring such diverse and time-limited political interactions is no easy task. Heterogeneous and unstable processes are diverse, elusive, and therefore hard to realistically model. Even so, both theory and comparative experience offer some order within the confusion. Both the contentious politics literature and Hirschman's framework offer valuable theoretical contributions.

\section{Chile}

This preliminary portrayal of protest politics is inevitably exploratory and incomplete. Its limitations will soon emerge in this new Journal, which should provide pointers toward a fuller portrait. With so much unfinished here, the best conclusion may be a currently ongoing illustration-the Chilean protests of late 2019 that have become known as the Estallido Social.

This nationwide outburst was the culmination of a very long and mounting sequence of more fragmentary protests. It has precipitated a drastic break with the past, which has been channeled through a massive and undirected horizontal outburst without much visible leadership and which expresses frontal rejection of the existing political order in its entirety. It was inspired by a unifying idea (no more subordination to an imposed neoliberal ascendancy). This 
was an exceptional "upscaling" of protest (a key concept for the contentious politics school).

Ostensibly this was a social protest movement, with the apparent trigger having been a small rise in subway fares (cf Rossi 2020). Political leaders and electoral movements (like the Frente Amplio) had worked closely with earlier street protests but were swept to one side by this one. There was a certain amount of violence from the start, but what really radicalized the population was when the carabineros began firing rubber bullets directly into the faces of participants. About two hundred were blinded, and the government's legitimacy was destroyed. It was obliged to convene a plebiscite on fundamental constitutional reform. One year later this national consultation produced a crushing majority in favor of the election of a constituent assembly, which was charged with overhauling the 1980 charter imposed by the Pinochet dictatorship. Marginalized and excluded voices would regain a fair hearing. Whatever the new settlement, the estallido ensures Chile a fresh start.

This estallido social mutated into the rupture of an entire political system. This was not just any system-it was Chile's much celebrated trajectory of supposed democratic consolidation. What this particular eruption confirms is that general classification models and typologies only take the analyst so far. Each society demands analysis on its own terms. Protest dynamics are driven by ideas that gain traction in the community and thereby acquire a life of their own, independent of external stipulations.

\section{References}

Benford, Robert D. and David A. Stone. "Framing Processes and Social Movements: An Overview and Assessment." Annual Review of Sociology 26 (2000): 611-639.

Bishara, Dina. "The Politics of Ignoring: Protest Dynamics in Late Mubarak Egypt." Perspectives on Politics 13, no. 4 (December 2015): 958-975.

Cammaerts, Bart, Alice Mattoni, and Patrick McCurdy, eds. Mediation and Protest Movements. Bristol: Intellect, 2013 .

Castells, Manuel. Networks of Outrage and Hope. Cambridge: Polity, 2012.

Chenoweth, Erica and Maria Stephan. Why Civil Resistance Works: The Strategic Logic of Nonviolent Conflict. New York: Columbia University Press, 2011.

Dalton, Russell J. and A. Van Sickle. The Resource, Structural, and Cultural Bases of Protest. Center for the Study of Democracy: University of California, Irvine, 2005.

Della Porta, Donatella. "Social Movements." In The Sage Handbook of Political Science Vol 2, edited by Dirk Berg-Schlosser, Bertrand Badie, and Leonardo Morlino. London: Sage, 2020. 
Della Porta, Donatella and Sidney Tarrow, eds. Transnational Protest and Global Activism. Lanham, MD: Rowman and Pitman, 2005.

Durac, Vincent. "Social movements, protest movements and cross-ideological coalitions: the Arab risings reappraised." Democratization 22, no. 2 (March 2015): 239-258.

Francis, Megan Ming. Civil Rights and the Making of the Modern American State. New York: Cambridge University Press, 2014.

Freeden, Michael. The Political Theory of Political Thinking. Oxford: Oxford University Press, 2013 .

Gamson, Wiliam A. The Strategy of Social Protest Belmont, CA: Wadsworth, 1990.

Gurr, Ted Robert. Why Men Rebel. Princeton NJ: Princeton University Press, 1970.

Gurr, Ted Robert. Why Men Rebel: Fortieth Anniversary Edition. Boulder: Paradigm, 2011.

Hirschman, Albert O. Exit, Voice and Loyalty:Responses to Decline in Firms, Organizations and States. Cambridge: Harvard University Press, 1970.

Hirschman, Albert O. "Exit, Voice, and Loyalty: Further Reflections and a Survey of Recent Contributions.” Social Science Information 13, no. 1 (1974): 7-26.

Hussain, Muzammil M. and Philip N. Howard. "What best explains successful protest cascades? ICT s and the fuzzy causes of the Arab spring." International Studies Review 15, no. 1 (March 2013): 48-66.

Jasper, James M. “Constructing Indignation: Anger Dynamics in Protest Movements.” Emotion Review 6, no. 3 (June 2014): 208-213.

Ketchley, Neil. Egypt in a time of revolution: contentious politics and the Arab spring. Cambridge: Cambridge University Press, 2019.

Kingstone, Peter, J.K. Young, and R. Aubrey. "Resistance to Privatization: Why Protest Movements Succeed and Fail in Latin America." Latin American Politics and Society 55, no. 3 (Fall 2013): 93-116.

Klandemans, P.G. "Identity Politics and Politicized Identities: Identity Processes and the Dynamics of Protest." Political Psychology 35, no. 1 (February 2014): 1-22.

Koopmans, R and D. Rucht. "Protest Event Analysis" in Klandemans B and S. Staggenborg Methods in Social Movement Research. Minneapolis: Minnesota University Press, 2002.

Kriesi, Hnspieter, R. Koopmans, J.W. Duyvendak, and M.G. Guigni. New Social Movements in Western Europe; A Comparative Analysis. Minneaplois; Minnesota University Press, 1995.

Kriesi, Hanspieter, Swen Hutter, and Abel Bojar. "Contentious Episode Analysis." Mobilization 24, no. 3 (Sept 2019): 251-273.

Maddison, Sarah and Marian Sawer, eds. The Women's Movement in Protest, Institutions and the Internet: Australia in Transnational Perspective. London: Routledge, 2013. 
McAdam, Doug, Sidney Tarrow, and Charles Tilly. The Dynamics of Contention. Stanford, CA: Stanford University Press, 2001.

Moseley, Mason W. Protest State: The Rise of Everyday Contention in Latin America. Oxford; Oxford University Press, 2018.

Onuch, Olga and Gwendolyn Sasse. "The Maidan in Movement: Diversity and the Cycles of Protest." Europa-Asia Studies 68, no. 4 (2016): 556-587.

Rich, Jessica. State-Sponsored Activism: Bureaucrats and Protest in Brazil. Cambridge: Cambridge University Press, 2019.

Rootes, C. Environmental Protest in Western Europe. Oxford: Oxford University Press, 2003.

Rossi, Federico. Oxford Handbook of Latin American Social Movements. Oxford: Oxford University Press, 2020.

Rucht, Dieter. "The Spread of Protest Politics." In Russell J. Dalton and Hans-Dieter Klingemann, eds. The Oxford Handbook of Political Behavior. Oxford: Oxford University Press, 2007.

Snow, David A. and Dana M. Moss. "Protest on the fly: Toward a theory of spontaneity in the dynamics of protest and social movements." American Sociological Review 79, no. 6 (December 2014): 1122-1143.

Tarrow, Sidney. Power in Movement. New York: Cambridge University Press, 1994.

Tarrow, Sidney. Movements and Parties: Critical Connections in American Political Development. Cambridge: Cambridge University Press, 2021.

Tilly, Charles. Regimes and Repertoires. Chicago: Chicago University Press, 2010.

Tilly, Charles and Sidney Tarrow. Contentious Politics. Oxford: Oxford University Press, 2nd edition, 2015.

Touraine, Alain. La Voix et le Regard. Paris: du Seuil, 1978.

Tufekci, Zeynap. Twitter and Tear Gas: The Power and Fragility of Networked Protest. New Haven: Yale University Press, 2017.

Weber, Max. The Theory of Social and Economic Organization. Oxford: Oxford University Press, 1947 .

Whitehead, Laurence. “'Aversive' Democracy, 'Contentious' Politics, and 'Agonistic' Populism: Comparative Experience and Implications for Contemporary North Africa." Journal of North African Studies 25, no. 6 (2020): 881-895.

Yan, Xiaojun, Grzegorz Ekiert and Elizabeth J. Perry, eds. Ruling by Other Means: StaeMobilized Movements. Cambridge: Cambridge University Press, $202 \mathrm{O}$.

Zald, Mayer N., John D. McCarthy and William A. Gamson. Social Movements in an Organizational Society. New York: Routledge, 1987. 